\title{
A Review on Board Network and the Enterprise Investment Convergence
}

\author{
Menglin Liu \\ International Business School \\ Shaanxi Normal University \\ Xi'an, China
}

\begin{abstract}
Corporate investment is one of the core research issues in the field of corporate finance. The individual behavior of directors is embedded in the social network and influences the effectiveness of corporate investment behavior. However, traditional research ignores the role of network relationship. In recent years, many scholars in the field of corporate finance and governance have gradually studied it from the perspective of social network. This paper summarizes the definition of board network, the relationship between the board network and convergence of investment. It is found that the board network has an effect on the convergence of corporate investment. Also, in the existing studies, the definition of the board network are fuzzy.
\end{abstract}

Keywords—social network; board network; investment convergence

\section{INTRODUCTION}

Driven by big data processing technology and complex social network analysis technologies, the cross-study of social network and corporate finance becomes a hot issue in recent years. However, there is a lack of relevant literature in China, and the research on this issue needs to be further explored. In the existing literature on the investment behavior of a company characterized by the board of directors, most studies are conducted based on the characteristics of directors themselves, such as considering the influence of their age, occupation, educational background, gender and other factors However, as a member of the economic society, directors are in a complex network relationship, and the differences in the social network will inevitably affect their own corporate governance behaviors (Yunsen Chen, 2011). From the perspective of network relationship, the importance of such implicit relationship characteristics of directors is obvious. The behavior of the director is not only simply depends on his personal characteristics, but also under the influence of social network in contact with others (Granovetter, 1985). Therefore in recent years, international corporate finance and corporate governance gradually studied in a social network perspective. In this paper, I summarizes the definition of board network, and the relationship of board network and corporate investment behavior. It is found that the interlocking board network between companies becomes an informal access channel and an important information bridge for policy making information. The influence of centrality, structure hole and aggregation of the listed company in the board network on its over-investment level and the moderating effect of the quality of external information resources on the above influence; The higher the centrality of the company in the board network, the higher the investment efficiency.

As a paradigm, social network theory and its analytical methods have been extended to the fields of psychology, economic sociology, strategic management, marketing, knowledge management, etc. Literature review in different fields has also well sorted out the development of relevant disciplines. Introduction of social network in the field of corporate governance paradigm is relatively late, especially from a network perspective of director of literature for research has just started, from the point of the literature, many basic problems such as the director of the concept of network, network relations play a role of the controversial, this article from the board network relationship definition, board network and corporate investment behavior were summarized. I found that in the existing studies, the definition and boundary of board network are fuzzy, and the measurement standards of centrality are inconsistent.

\section{DEFINITION OF BOARD NETWORK}

Granovetter (1985) argues that the behavior of the individual rather than simply depend on his own, but at the same time the influence of social network in contact with others, Ellison and Fudenberg (1995) found that he does not know the choice agent must often make cost-benefit ratio between decisions, they do not choose objective research or experiment was carried out, and often rely on each other from random oral communication information can be obtained Social network theory emphasizes the individual depends on the behavior of others to change their own preferences and decided to decision externalities (decision externality), any economic organizations or individuals with certain "social relationship" with the outside world (relationship) and "coupling" (tie), Mosaic or suspended in a by a variety of relations connecting multiple and complex, interwoven into the overlapping of the social network. The formation of this social network does not need any formal group or organizational ceremony, but occurs and develops due to the interaction process such as contact, communication, communication and exchange between people (bian yanjie and qiu haixiong, 2000) In the field of corporate governance, one kind of social network relationship that cannot be ignored is the relationship between directors. Fama and Jensen (1983) pointed out that most external directors were important decision-makers of other 
companies' management or other organizations, and their behaviors and communication in other organizations and companies would inevitably affect their behaviors as directors of a certain company. On the surface, many directors have independent relationships in a company, but in fact they are connected through direct or board network of relationships.Kramarz and Thesmar (2006) found that social network can influence the composition of the board of directors, and is one of the important determinants of corporate governance, and Lu Changchong Chen Shihua (2009) found that China's capital market more than $80 \%$ after 2008 have chain directors of listed companies, this means that the a-share listed company's board of directors has formed A chain based on board to form A network, Moreover, xie deren and Chen yunsen (2012) found that the board network had an important impact on the governance behaviors and effects of directors through the analysis of the network relationship of "top 10 outstanding independent directors of listed companies in 2010". The definition of board network in existing literature is mainly distinguished from the network relations of directors with different natures, which can be generally divided into the following types: first, the network formed by directors based on their existing tenure relations. Such as Barnea wrote and Guedj (2009), Andres and Lehmann (2010) and Larcker et al. (2011), and other literature definition based on part-time directors (interlocking) produced by direct and indirect coupling relation, and board network, which formed in the way of communication between the main board directors from all kinds of formal occasions or private exchanges. Communication methods of directors with different natures are different. Communication between independent directors and internal directors, as well as between independent directors, is mainly through communication between the company's board of directors, professional committee meetings and informal occasions. Since internal directors may hold positions in the management of the company at the same time and belong to the relationship between colleagues or superiors and subordinates, they have more time and opportunities for contact, communication and communication, and different contact and communication methods generate different network connection relations. Xie deren and Chen yunsen (2012) defined the board network as "the collection of individual directors of a company's board of directors and the connecting relationship between directors who hold office in at least one board of directors at the same time", and pointed out the leading role of independent directors in the board network. The second is based on the professional background of directors. For example, Bizjak et al.(2009), Farina(2009), Kuhnen(2009) and Chiu et al.(2010) conducted the study by studying the business relationship or connection generated by the nature of the position formed by the past occupation between directors; The third is based on the director's education and other background.Nguyen(2009) studied whether directors and management are connected in the same elite education institute or elite internal service organization. Hwang and Kim (2009) defined the informal connection between the management and independent directors in the same school, military service, region, professional organization, etc. as the social joint relationship. There is also a literature that defines web connectivity relationships based on a variety of properties, such as Fracassi and Tate(2008) and Fracassi(2008), which use data on directors' current occupations, past occupations, education, and other activities as social links for directors. Domestic scholars have two understandings of the concept of board network. Some scholars believe that director network is a network form formed by taking the company as the network node and the interlocking director as the network connection. In terms of quantitative analysis, the structure attribute of the company in the social network can be directly calculated. In addition, some scholars believe that board network is a network form formed by director as the network node and director's joint tenure as the network connection. In terms of quantification, the structural attributes of directors in the social network should be calculated first, and then aggregated into corporate attributes through averaging and other methods.

Social network is made up of nodes and the coupling relationship between collections, and therefore, respectively, from the perspective of the nodes and relationships to clarify the boundary of the "board network" : in this paper, first of all is the board network node boundary, at the time of quantitative research director of the network, if not fully individuals, including all the relevant directors then some network nodes may be artificially partition and make the quantitative description data distortion. The boundary of directors than the existing network research more complete than the advantage of network nodes, they choose more research part of the listed companies, such as Wong and Gygax (2009) use the S\&P 1500 companies in the United States, Barnea wrote and Guedj (2009) use the S\&P 1500 companies in the United States, it is artificially partition of other companies in the same environment network (such as a director in the S\&P 1500 companies as the independent directors, but united closely with him director of the company are not in the S\&P 1500 companies, The calculated network centrality of the director will be smaller than the reality), which will cause deviation of the measurement results of empirical research.

The second is the boundary of the connecting relationship in the board network. Directors not only play a role on the corporate board of directors, but also play a number of other social roles, such as corporate executives, industry association leaders, government officials, university professors, members of various clubs, fellow villagers and alumni associations, as well as "husband, wife, father and son of man". Directors with multiple social roles naturally have a variety of social network connections, such as professional associations, alumni networks, clubs, fellowships, in-laws and blood ties. 


\section{THE RELATIONSHIP BETWEEN BOARD NETWORK AND INVESTMENT CONVERGENCE}

Traditional corporate finance theory holds that a company's decision-making is independent and ignores the influence of other companies or individuals on the company's decisionmaking behavior. In recent years, the "convergence effect", "imitation effect" and "group effect" of corporate financial policies have gradually attracted the attention of domestic and foreign scholars. Leary et al. found that corporate financing policies were significantly influenced by other companies in the same industry, and there was a significant "peer group effect".Kaus tia et al. also found that the financing decision of additional issuance of peer enterprises would also significantly affect the company's decision of additional issuance. There was a significant industry "peer group effect" in the merger and acquisition decisions of Chinese listed companies. Chen shihua found that the "imitation effect" of companies with executive connection is more significant, and executive connection makes companies more likely to imitate the m\&a decision of the connected companies. Parsons et al. also found that corporate financial irregularities also have a regional "peer group effect." From the perspective of board network relationship, Kang et al. found that if the company's internal directors interlocked with other companies that had made the voluntary expensification decision of stock option grant, or interlocked with the board of directors of institutional investment companies that had invested in financial fraud companies, the company would be more likely to voluntarily expensify stock options. Bizjak et al. found that if a member of the board of directors had engaged in similar backdating behaviors in other companies before, the possibility of backdating stock options in the company would be greatly increased. Chiu et al. found that if a company is connected to another company through chain directors, and the related company had financial restatement events in the current year or the previous two years, then the probability of financial restatement of the company is also greater, and this transmission effect is stronger when the chain directors are chairman of the board of directors and members of the audit committee. Chen yunsen found that if there is a interlocking board network between two companies, the investment level and investment changes between companies are more similar, and the convergence effect is strengthened with the increase of the strength of interlocking board network. In addition, the worse the information environment of the company is, the higher the demand is for the director interlocking network relationship, which is an informal information transmission channel. Further, when two companies are in the same industry, the effect of interlocking board network on investment convergence between companies is more obvious. The effect of non-independent director interlocking network relationship on investment convergence between companies is stronger than that of independent director interlocking network relationship.

The main revelation I get from the above literature is that the influence of social network can make people have a systematic and predictable effect on the influence of directors on corporate policies, thus leading to the convergence of various corporate activities.

\section{CONCLUSION}

As a kind of social network, the network boundary of board network is not clear, which leads to some studies to artificially cut off many network relations, thus easy to draw wrong conclusions. For example, Barnea and Guedj (2009) and Fracassi and Tate(2012) used the board of directors of S\&P1500 company to calculate the network relationship of the whole directors, which artificially cut off many companies that were not included in this scope, thus making the network position index deviated. Therefore, the strict definition of board network, especially the definition of network boundary, becomes inevitable. As crossover study of corporate governance and social network, more just on the surface of the existing literature analysis director, which is based on the network relations of different shows in the advantage of information transfer, and its reputation, and is limited by social network communication and human care of disadvantage, but not to the director of network of researches in social network features, such as the weak link in the theory of social superiority theory, structural hole theory and so on in different network structure, network type, directors have the difference between network characteristics.

It is a new direction to study the efficiency of corporate investment based on the network of directors in social network. There are some deficiencies in the existing literature on network analysis. First, the definition of director network is not clear, so the director network established is not the same. Second, the network boundary of director network is not clear, which leads to some studies being cut off many network relations artificially, which is easy to lead to the deviation of research results. In the subsequent network analysis, the network of different relationships can be established from different perspectives to make further research on the board network.

\section{REFERENCES}

[1] Granovetter M., 1985, "Economic Action and Social Structure: The Problem of Embeddedness". American Journal of Sociology, 91 (3), 481-510.

[2] Ellison G., Fudenberg D., 1995, "Word-of-mouth Communication and Social Learning", Quarterly Journal of Economics, Vol.110, No.1, pp.93-125.

[3] Fama, E. F. and Jensen,M. C., 1983, "Separation of Ownership and Control" Journal of Law and Economics. (26) : 301-325.

[4] Yunsen Chen, Deren Xie,2012, Director network, independent director governance and executive motivation, Journal of Financial Research (2) pp.173-189. (In Chinese)

[5] Bizjak J., Lemmon M. and Whitby R.,. 2009, “Option Backdating and Board Interlocks" The Review of Financial Studies (22),4821 - 4847.

[6] Farina V., 2009, "Banks' Centrality in Corporate Interlock Networks and Evidences in Italy" Working paper.

[7] Nguyen B. D., 2009, "Dose the Rolodex matter? Corporate Eite's Small World and the Effectiveeness of Board of Directors," Working paper.

[8] Hwang YS. and Kim YN., 2003, "It Pays to have Friends" Journal of Financial Economics, (93),pp. $138-158$.

[9] Chiu P. C., Teoh S. H. and Tian F., 2010, "Board Interlocks and Earnings Management Contagion" Working Paper.

[10] Larcker D. F., E. C., Wang, C. C. Boardroom Centrality and Firm Performance. Journal of Accounting and Economics, 2013, 55(2): 225250 . 
[11] Subrahmanyam A., 2008. "A Social Networks and Corporate Governance" European Financial Management, 14(4), 633-662.

[12] Liu Y, 2010, "The Role of Networks in the CEO and Director Labor Market" Working paper.

[13] Kuhnen C. M., 2009, "Business Networks, Corporate Governance, and Contracting in the Mutual Fund Industry" Journal of Finance. (5) 2185 -2220 .

[14] Kim Y., 2005, "Board Network Characteristics and Firm Performance in Korea Corporate Governance, An International Review"13(6), 800808 .

[15] Shihua Chen, Wenquan Zheng,2010, Recent developments in corporate governance theory: a new analytical framework, Management World (2) pp156-166.(In Chinese)

[16] Yunsen Chen, Deren Xie,2011,Network location, independent director governance and investment efficiency. Management World. (7) pp113127(In Chinese)

[17] Yunsen Chen, 2015, Social networks and enterprise efficiency: evidence based on the location of structural holes, Journal of Accounting Research. (1), pp48-55+97. (In Chinese)

[18] Changchong Lu, Shihua Chen, 2009, Reconstruction of broken connections: interlocking directors and their organizational functions, Management World. (5) pp152-165. (In Chinese)

[19] Liangyong W, Chanjjuan L, Jing R. 2016Study on industry peer group effect of merger and acquisition decision of listed companies. Nankai Business Review. 19(3)PP40-50. (In Chinese)

[20] Liangyong W, Jing H, 2014, Network location, independent director governance and corporate mergers and acquisitions -- empirical evidence from Chinese listed companies, Nankai Business Review.(2)pp64-73. (In Chinese) 